\title{
Leptolepis, Paraleptolepis (Teleostei) and a New Fish Name
}

\author{
Gloria Arratia ${ }^{1}$
}

With 1 figure

\begin{abstract}
A new genus and species, Paraleptolepis wiedenrothi Arratia \& Thies, 2001 was recently described from the Lower Jurassic Posidonia shale of northern Germany. Unfortunately, the name Paraleptolepis is currently occupied by a Japanese fish genus of Early Cretaceous age, which is unrelated to the so-called leptolepiforms. A new name, Longileptolepis, is proposed for the German Toarcian genus. Differences between both genera are discussed.
\end{abstract}

Key words: Fishes, Teleostei, Paraleptolepis, Longileptolepis, new name, Jurassic, Early Cretaceous.

\section{Zusammenfassung}

Eine neue Gattung und Art, Paraleptolepis wiedenrothi Arratia \& Thies, 2001 wurde kürzlich aus den unterjurassischen Posidonienschiefern Norddeutschlands beschrieben. Leider ist der Name Paraleptolelpis für eine japanische Fischgattung frühkretazischen Alters präokkupiert; diese Form ist nicht mit den sogenannten Leptolepiformen verwandt. Ein neuer Name, Longileptolepis, wird für die Gattung aus dem deutschen Toarcium vorgeschlagen. Die Unterschiede zwischen beiden Gattungen werden diskutiert.

Schlüsselwörter: Fische, Teleosteer, Paraleptolepis, Longileptolepis, neuer Gattungsname, Jura, Unter Kreide.

\section{Introduction}

Leptolepis is a name mistakenly used in fish collections to identify small teleosts, mainly of Jurassic age. This same problem applies to the general usage of "leptolepid", for small fossil fishes of generalized, primitive teleostean morphology.

Agassiz (1832) coined the term Leptolepis for L. bronni, a small fish species occurring in Upper Liassic strata of England, France and Germany. Following rules of zoological nomenclature, the name of the type species of the genus is not L. bronni but Leptolepis coryphaenoides, a species earlier described as Cyprinus coryphaenoides by Bronn (1830). Thanks to the extensive research on European Jurassic "leptolepids" by Nybelin (1974), the genus Leptolepis was restricted to few European species of Early Jurassic age and the remainding European species were assigned to the genera Ascalabos, Tharsis and Leptolepides. Although Nybelin
(1974) restricted the family Leptolepididae to the genera Proleptolepis and Leptolepis and provided new diagnoses for these taxa, most of his diagnostic features are primitive so the problem of identifying "leptolepids" continues.

Recently, Arratia \& Thies (2001) described a new teleost from the Lower Jurassic Posidonia shale of northern Germany. The fish was considered a new genus and species, Paraleptolepis wiedenrothi. A few months after the publication of $P$. wiedenrothi, I was informed of the existense of a paper by Y. Yabumoto, in the Bulletin of the Kitakyushu Museum of Natural History (Japan), regarding Yabumoto (1994) placement of the Japanese new genus Paraleptolepis in a order and family incertae sedis. He implied in the selection of the name that the fishes are "beside or near" Leptolepis. Certainly, the features of the Japanese fishes do not belong to members of Leptolepis nor Leptolepididae (see below) or a close related taxon. However, following the rules of taxonomic nomenclature, the name has prior-

\footnotetext{
1 Museum für Naturkunde der Humboldt Universität, Invalidenstr. 43, D-10115 Berlin, Germany. Received January 2003, accepted March 2003
} 
ity for the Japanese Cretaceous fishes and consequently the election of Paraleptolepis for the Early Jurassic genus of Germany is wrong. The goals of this contribution is to correct such a mistake, to complete a new restoration of the German "leptolepid" and clarify the differences between the German and Japanese taxa.

\section{Systematic paleontology}

Division Teleostei sensu Arratia 1999, 2001

Teleostei incertae sedis

Family indeterminate

\section{Longileptolepis n. gen.}

\section{Synonym:}

2001 Paraleptolepis - Arratia \& Thies: 169, figs 3-12.

Diagnos is (based on a unique combination of features including several autapomorphies): Elongate, fusiform fish with few skull bones covered with a thin layer of ganoine and lacking ornamentation. Premaxilla with well-defined, long ascending process; with few conic teeth on oral margin. Two moderate large suborbital bones $(*)$. Preopercle subtriangular in outline and with a notch at its posterior margin $(*)$; most tubules of preopercular sensory canal not reaching the ventral and posterior magins of preopercle. Opercle slightly triangular and with crenulate posterior margin $(*)$. Subopercle larger than opercle and broadly expanded postero-ventrally $(*)$. Large cleithrum with a pronounced curvature at its anterior margin $(*)$. Pelvic axillary process formed by only an elongate small bone $(*)$. Caudal skeleton with narrow, elongate neural spines. Preural centrum 1 with long neural spine. Ural centrum $1+2$ with unfused neural arch bearing an elongate spine. Both epaxial and hypaxial fringing fulcra. Two dorsal and one ventral caudal scutes. Thin cycloid scales lacking ganoine. (Unique characters among basal teleosts are identified by [*]).

Etymology: The name of the genus refers to the larger size of the fishes in comparison with that of members of Leptolepis and Proleptolepis.

Type-species: Longileptolepis wiedenrothi (Arratia \& Thies, 2001).

\section{Longileptolepis wiedenrothi (Arratia \& Thies)}

Fig. 1

\section{Diagnosis: As for genus}

Holotype: MB. f.7612, nearly complete specimen (Museum für Naturkunde der HumboldtUniversität zu Berlin, Institut für Paläontologie).

Type-locality and age: Salzgitter-Haverlahwiese, SW of Braunschweig, Germany (Arratia \& This 2001: fig. 1). Early Jurassic, Toarcian.

Description: For a detailed description of the species see Arratia \& Thies (2001).

\section{Comments}

Paraleptolepis kikuchi and P. elegans, from the Lower Cretaceous of Japan are known from incompletely preserved specimens so their features are poorly known. In contrast, the better preservation of Longileptolepis wiedenrothi permits a more concise morphological description, and consequently, a more complete restoration (Fig. 1) than the Japanese species (compare Fig. 1 with figures 87 and 91 in Yabumoto 1994).

Longileptolepis is distinct and morphologically varied from Paraleptolepis. This is evidenced by:

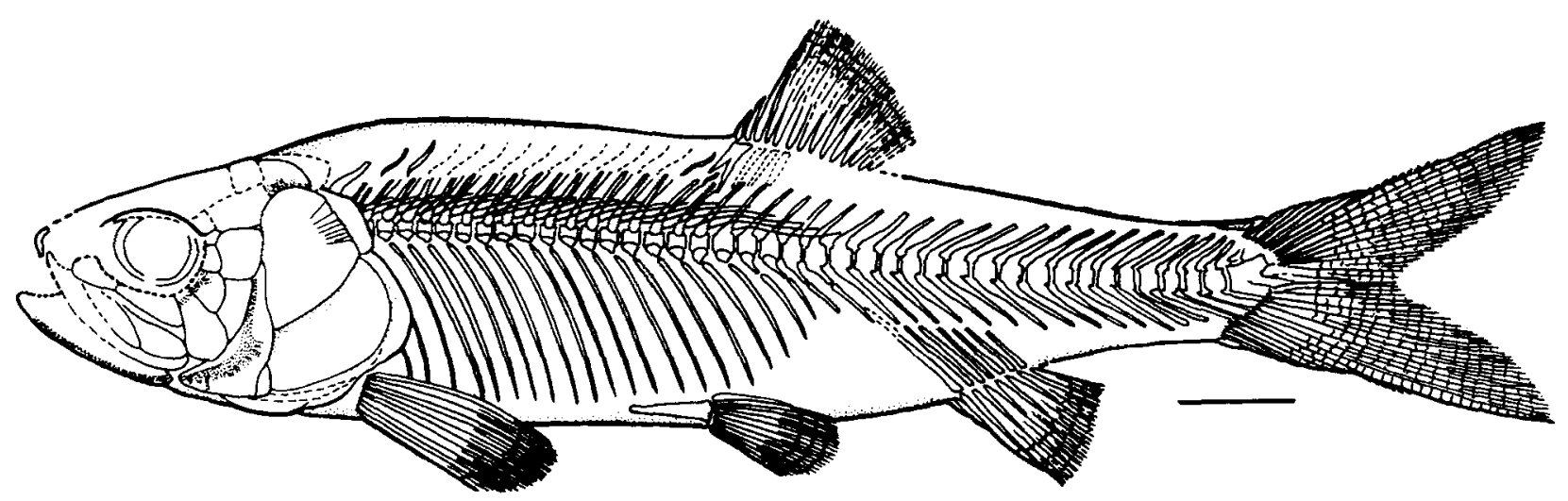

Fig. 1. Restoration in lateral view of Longileptolepis wiedenrothi from the Early Jurassic of Salzgitter-Haverlahwiese, near Braunschweig. Scale $=3 \mathrm{~cm}$. 
1. The parietal bone [ = frontal of traditional terminology] is short and broad in Paraleptolepis (Yabumoto 1994), but it is elongate anteriorly and characteristically broader posteriorly in Longileptolepis (as well as in Proleptolepis and Leptolepis).

2. One supramaxilla is apparently present in Paraleptolepis (Yabumoto 1994), whereas two broad, well defined supramaxillaries are found in Longileptolepis (as well as in Proleptolepis and Leptolepis).

3. Paraleptolepis is diagnosed by an absence of teeth on the maxilla and the presence of canine-like teeth on premaxilla and dentary (Yabumoto 1994). Longileptolepis bear minuscule conic teeth on premaxilla and maxilla (condition of dentary unknown).

4. Epineural processes or bones were not mentioned nor illustrated for Paraleptolepis (see Yabumoto 1994). Long epineural processes associated with the neural arches of the abdominal vertebrae are present in Longileptolepis (Fig. 1). Similar processes are present in Leptolepis.

5. Paraleptolepis has $40-42$ vertebrae. Longileptolepis has over 44 vertebrae (Fig. 1), a count more similar to that of Leptolepis coryphaenoides.

6. Paraleptolepis has three uroneurals whereas Longileptolepis has five or more elongate narrow uroneurals (Arratia \& Thies 2001: figs 10B, 11). Leptolepis coryphaenoides has commonly seven (Arratia 1991: fig. 7).

7. There are 18 principal caudal fin-rays in Paraleptolepis kikuchii and P. elegans. Longileptolepis and Leptolepis coryphaenoides share the primitive higher count of 19 principal caudal rays (Arratia 1991).

8. Basal fulcra were not reported nor illustrated for Paraleptolepis. Longileptolepis and Leptolepis coryphaenoides have epaxial basal fulcra.

9. Paraleptolepis lacks fringing fulcra in the caudal fin. Longileptolepis has both series of epaxial and hypaxial fringing fulcra. Only a series of epaxial fringing fulcra is present in Leptolepis coryphaenoides.
In sum:

Paraleptolepis is the valid generic name for two fossil species from Minamigaoka, Kokura-kitaku, Kirtakyshu City, Fukuoka Prefecture, Japan. Freshwater Lower Cretaceous deposits.

Longileptolepis new generic name replaces that of Paraleptolepis widenrothi from SalzgitterHaverlahwiese, SW of Braunschweig, Germany. Marine Lower Jurassic deposits.

\section{Acknowledgements}

My thanks to A. López-Arbarello (Berlin) for calling my attention concerning the name Paraleptolepis and to Y. Yabumoto for making available to me, a copy of his monograph. C. Chang-Arratia (New York) revised the style.

\section{References}

Agassiz, L. 1832. Untersuchungen über die fossilen Fische der Lias-Formation. - Jahrbuch für Mineralogie, Geognosie und Petrefaktenkunde 3: 139-149.

Arratia, G. 1991. The caudal skeleton of Jurassic teleosts. In Chang, M-M., Liu, Y. H. \& Zhang, G. R. (eds). Early Vertebrates and Related Problems in Evolutionary Biology: 249-340, Science Press, Beijing.

- 1999. The monophyly of Teleostei and stem-group teleosts. Consensus and disagreements. In Arratia, G. \& Schultze, H.-P. (eds). Mesozoic Fishes 2 - Systematics and Fossil Record: 265-334, Verlag Dr. F. Pfeil, München.

- 2001. The sister-group of Teleostei: Consensus and disagreements. - Journal of Vertebrate Paleontology 21 (4): 767-773.

Arratia, G. \& Thies, D. 2001. A new toleost (Osteichthyes, Actinopterygii) from the Early Jurassic Posidonia shale of northern Germany. - Mitteilungen aus dem Museum für Naturkunde in Berlin, Geowissenschaftliche Reihe 4: 167-187.

Bronn, H. 1830. Über zwei fossile Fischarten: Cyprinus coryphaenoides und Tetragonolepis semicinctus aus dem Gryphitenkalke bei Donaueschingen. - Jahrbuch für Mineralogie, Geognosie und Petrefaktenkunde 1: 13-40.

Nybelin, O. 1974. A Revision of the Leptolepid Fishes. Acta Regiae Societatis Scientiarum et Litterarum Gothoburgensis, Zoologica 9: 1-202.

Yabumoto, Y. 1994. Early Cretaceous Freshwater Fish Fauna in Kyushu, Japan. - Bulletin of the Kitakyushu Museum of Natural History 13: 107-254. 